\title{
Presenting Ottoman Childhoods in Post-Ottoman Autobiographies
}

\author{
Philipp Wirtz
}

While many of the personal narratives to come out of the turbulent era that is the late Ottoman Empire are political memoirs dealing with weighty matters of state, there are also a large number of autobiographical texts that deal with their authors' personal development. In the following chapter in this volume, Duygu Köksal presents two examples of such life stories; here, I examine a broader selection of authors in order to survey some dominant topics treated in autobiographical narratives of childhood in the Ottoman world.

The first section considers the influence of parents and other relatives, a subject to which most of the authors I am considering devote a lot of attention. The next topic is the physical environment in which authors spent their childhood: the house, and sometimes a garden, and the neighbourhood or town quarter [mahalle]. In the third section, I investigate some examples of how what I call 'childhood culture' is remembered. Under this topic, I count games and other pastimes, as well as cultural activities like the telling and reading of folktales. One very interesting aspect of 'childhood culture' which should be considered is the perceived or actual clash of 'new' and 'old' worlds, of structures and customs which had been in place for a long time, in relation to new cultural phenomena brought about by the reforms of the nineteenth century. These clashes are sometimes recounted by authors in a childhood context, as they were perceived as either positive or noteworthy, or as faultlines in otherwise peaceful family lives.

Narratives of childhood are found in many of the autobiographies produced in the late Ottoman and early Turkish Republican era; some accounts are very extensive, and some autobiographies actually have the author's childhood as their main focus. For this chapter, I have tried to assemble examples from a variety of texts to convey a sense of the plurality of backgrounds and experiences. Given that not every autobiography gives the same amount of space to childhood experiences, it is inevitable that some authors make shorter appearances in this paper than others; also, in order to avoid repetition, I have not always recounted the whole childhood section of every autobiography used.

The history of childhood is a comparatively young discipline, starting with Philippe Ariès' work, and especially his Centuries of Childhood (1962). Since

(C) PHILIPP WIRTZ, 2016 | DOI 10.1163/9789004305809_011

This is an open access title distributed under the terms of the Creative Commons Attribution- 
then, historians have 'discovered' the child and childhood as objects worthy of their interest. ${ }^{1}$ While many of the seminal early works on this subject focused on Europe, the latest development is the consideration of childhood in a global context, including the Middle East. ${ }^{2}$ The value of first-person narrative in studying Middle Eastern childhoods has been widely acknowledged, and autobiographies penned in the Middle East are becoming increasingly available to the non-specialist reader in translations. It should be noted, however, that this type of narrative does not always come neatly labelled as a dedicated autobiographical narrative - a book dedicated to the memories of a person identical with the author on the title page - as understood by Philippe Lejeune's concept of the 'autobiographical pact.'3 The autobiographical monograph, as Dwight Reynolds suggests, is a fairly recent development in Middle Eastern literatures, dating to the late nineteenth to early twentieth century. Before this, personal reflections have to be gleaned from sources as varied as travel accounts, biographical dictionaries or works of mystical reflection. ${ }^{4}$ While my analysis of necessity presents only a small selection from the autobiographical narratives available, it is hoped that this paper on remembering childhood will provide a small contribution to this effort.

\section{Family Circles: Parents and Other Relatives}

The journalist and newspaper editor Ahmed Emin Yalman (1888-1972) begins his autobiography ${ }^{5}$ with recollections about his early childhood, starting with

1 For a concise introduction into this field, see Heidi Morrison, "What is the Global History of Childhood?" in Heidi Morrison (ed.), The Global History of Childhood Reader (Abingdon: Routledge, 2012), 1-8. A broader synopsis is provided in Ulrike Freitag and Nora Latfi, "Daily Life and Family in an Ottoman Urban Context: Historiographical Stakes and New Research Perspectives," History of the Family, 16 (2), 2011, 80-87.

2 For a recent, carefully edited anthology of Turkish childhood memory narratives in German translation, see Klaus Kreiser and Patrick Bartsch (eds), Türkische Kindheiten (Frankfurt am Main: Literaturca, 2012).

3 Philipp Lejeune, On Autobiography, translated by Katherine Leary (Minneapolis: University of Minnesota Press, 1989), 3-30.

4 Dwight F. Reynolds, "Childhood in One Thousand Years of Arabic Autobiography," Edebiyât, 7, 1997, 380 ff. For a more detailed study of this, see id.(ed.), Interpreting the Self:Autobiography in the Arabic Literary Tradition (Berkeley: University of California Press, 2001). For the phenomenon of Sufi autobiography, the work of Cemal Kafadar has been ground-breaking, see his "Self and Others: The Diary of a Dervish in 17th Century Istanbul and First Person Narrative in Ottoman Literature," Studia Islamica, 69 (1989), 121-150.

5 Ahmed Emin Yalman, Yakın tarihte gördüklerim ve geçirdiklerim, 1 (Istanbul: Yenilik, 1970). 
a short sketch of his parents. The authors' father Osman Tevfik Bey is described as "very bright [uyanık], very active [hareketli], a very good man." His mother Hasibe Hanım matched his father in benevolence [iyilik], selflessness [fedakârlık] and love of good.

The positive picture of the author's parents is matched by his observations on his birthplace Salonica and the city's meaning for the Ottoman Empire. Yalman describes Salonica at the time of his birth as the Ottoman Empire's "main window to the West," and as more "liberal" [serbest] than any other part of the Ottoman lands; a city were the reforms of the nineteenth century, the period of re-ordering, or Tanzimat, took root most firmly. Thus it comes as no surprise that Yalman describes both his father and his birthplace with the same adjective, uyanık, meaning "bright" or "wide awake." He continues by stating that the outstanding position of Salonica was also due to the city's schools having been the best in the Empire and the most progressive. Yalman also relates in this context that his father was a teacher in these outstanding schools, a teacher of calligraphy at a time when having neat handwriting was considered a desirable skill. ${ }^{6}$ What is more, at some point he was the teacher of a boy named Mustafa, who was to become, as Mustafa Kemal Pasha, the future saviour of the nation. It becomes very obvious for us here how Yalman contextualizes and interweaves his father and his birthplace, the character traits of the former and the atmosphere of the latter.

It is intriguing to observe in this chapter's particular context of childhood, upbringing and the self that Ahmed Emin Yalman explicitly puts his own personality in the context of his birthplace's special atmosphere, as if the boy Ahmed could not have developed any other personality under the genius loci of late nineteenth-century Salonica. As the eldest child, Yalman was quite pampered and grew into a little rascal [afacan], who gave the servant girls entrusted with his care a hard time, but who could always count on the mild indulgence of his doting relatives. From very early on the boy showed a fervent "addiction to liberty" [hürriyete delice düşkündüm], and Yalman presents his own love of freedom to the reader of his autobiography as matching the progressive atmosphere in Salonica. The little adventures and misfortunes into which the "love of liberty and yearning for justice" [hürriyet sevgisi ve adalet hasreti] brought the boy are counted by Yalman as among his earliest memories. ${ }^{7}$

The officer and politician Kâzım Karabekir (1882-1948) puts his own family history into the wider context of Anatolian history from the beginning of

6 Ibid., 11.

7 Yalman, Yakın tarihte, 13 . 
Hayatım, ${ }^{8}$ his collection of autobiographical notes, establishing a lineage of warriors reaching back to Seljuq times. As his autobiography progresses, Karabekir gives the reader some further background on his parents and other relatives. His father is first introduced with an anecdote that reflects Karabekir's concern with showing himself as part of an ancient family of soldiers. He tells how, on the outbreak of the Crimean War, government officials came to the village of Kasaba, where his paternal grandfather had his estates, to register the young men of the area and enrol them for military service [asker yazmak üzere]. The peasants reacted by hiding their sons to avoid them being conscripted. The grandfather was "saddened" [müteessir] by this attitude and had his own son (Karabekir's father) conscripted first, in order to preserve the honour of the village. Everyone else followed his example, and the sons of Kasaba duly went to war. ${ }^{9}$ Karabekir continues with a description of his father's distinguished war service, first at the siege of Silistre ${ }^{10}$ and later in the Crimea, followed by other stages in his career."1

Karabekir also devotes a section to his mother, describing her ancestry and her personality, although in less detail than in the case of his father. Karabekir's mother originated from a family of merchants and landowners in Istanbul. Karabekir lists some of her noteworthy ancestors and briefly mentions his own recollections about his mother's family. ${ }^{12} \mathrm{He}$ continues by stating that, like his father, his mother was also from

a pure and in every respect noble Turkish family. In herself, she combined beautiful characteristics such as cleanliness, diligence, neatness, thriftiness, eloquence and love for her family. ${ }^{13}$

Yalman's and Karabekir's autobiographies are examples where a father takes centre stage in remembering one's childhood. Other authors put more emphasis on the role of their mothers. In some cases, the main importance of the mother is to balance the strict and harsh father by her friendly and loving character. One example is Hayat ve Hatratım, ${ }^{14}$ the vast autobiography by the

8 Kâzım Karabekir, Hayatım (2nd edition, Istanbul: Yapı Kredi Yayınları, 20og).

9 Ibid., 21.

10 Today, Silistra in northern Bulgaria. The Ottoman defenders of the city withstood a threemonth siege by the Russian Army in 1854 .

11 Karabekir Hayatım, 22-24.

12 Ibid., $25 \mathrm{ff}$.

13 Ibid., 26.

14 Rıza Nur, Hayat ve Hatıratım, 1 (Istanbul: Altındağ Yayınevi, 1967). 
doctor and politician Riza Nur (1879-1942). Hülya Adak, in her analysis of this work, has called Nur's multi-volume memoir a "misanthrography," referring to the negative treatment Nur metes out in the book to almost everyone he ever met in his life. According to Adak, Riza Nur's mother is the only person in the entire book apart from himself who is shown in a positive light. ${ }^{15}$

Nur's father is presented as a rather unlikeable character, a shoemaker who was called Mahmut Usta ("master Mahmut") or Mahmut Efendi on account of his knowing how to read and write. He is described as a harsh or strict [sert] man, who frequently beat his children. Although he sometimes behaved rudely towards her as well, Riza Nur's mother seems to have coped with her husband's behaviour and provided a milder, balancing influence in the family. Nur calls his mother "saintly" [mübarek]. He writes that he loved his mother "madly" [deli gibi], adding that however beautiful and intelligent the women he met in his later life were, he could never love any woman with the same intensity as he loved his mother. Nur describes her as a person who embodied a whole catalogue of positive qualities. Not only did she work tirelessly in the household, raise five children and help in the father's shop; she was also generally "efficient" and intelligent, to the point that "her every utterance had an inner meaning." Nur's mother never spoke up against her husband and she endured his uncouth ways without open complaint, only withdrawing into her room occasionally to cry in secret. ${ }^{16}$

He recalls one anecdote in particular which happened when he was studying medicine in Istanbul and came home to Sinop during his holidays. One day, he witnessed his father scolding his mother unjustly and then storming out of the house. Nur's mother then went to her room, where her son found her in tears. He grew angry, exclaimed "Enough already!" [artıkyeter!] and offered to confront his father. His mother, however, asked him not to do so, as such treatment was to be accepted, it being a woman's duty to obey her husband: "Their [women's] paradise is under their husbands' feet."17

Throughout his autobiography, Riza Nur is very concerned with presenting himself in a positive light. Accordingly, he states at the end of the passage referring to his mother's character that she passed all her good qualities on to her son, especially the love of virtue [fazilete sevkeden]. In an only slightly

15 Hülya Adak, "Who is Afraid of Rıza Nur's Autobiography?" in Olcay Akylldı, Halim Kara and Börte Sagaster (eds), Autobiographical Themes in Turkish Literature: Theoretical and Comparative Perspectives (Würzburg: Ergon, 2007), $138 \mathrm{ff}$.

16 Nur, Hayat, 55 .

17 Ibid., 56 . 
more humble tone, he adds that he would not have become what he became if it had not been for the way his mother had raised him. ${ }^{18}$

Another autobiography which presents the author's mother as an important figure is Bir devrin roman (1978), by the poet and novelist Halide Nusret Zorlutuna (1901-1984) $\cdot{ }^{19}$ Zorlutuna's mother appears at the very beginning of the narrative in a specific role: as a beautiful and gentle woman who teaches her small daughter how to read. As Halide Nusret's father was absent from the family during her early years (he was in exile until the Young Turk revolution in 1908), her mother naturally was the strongest influence in her upbringing. She is portrayed in a very positive way: as with the narratives of Karabekir and Nur, Zorlutuna's mother also stands for virtue, among other positive qualities. This view of virtue, when necessary, was imparted forcefully. Halide Nusret Zorlutuna remembers how she got the first beating of her life from her mother, for stealing fruit from a neighbour's garden. The author recalls that she did not cry, but rather her mother shed tears over meting out a necessary punishment to her beloved daughter. However, the lesson was a salutary one; Halide Nusret Zorlutuna states that from that day onwards, she never took anything that was not hers, not even "ownerless money I saw lying by the roadside."20

A happier memory of her mother is also connected to learning. Halide Nusret recalls how she was taught needlework by her mother together with her friend and playmate Fahriye, who later became a famous seamstress. In her teaching, Zorlutuna's mother acted like "a born pedagogue, tender but at the same time with authority;" the author is sure that her mother would have made an ideal teacher. ${ }^{21}$ Zorlutuna stresses repeatedly how intelligent and well-read her mother was: "My mother was after all a very intelligent woman who used her head, she neither drank coffee nor smoked cigarettes, the only strong addiction she had was to reading." ${ }^{22}$ That young Halide became a reader and, eventually, a writer is credited to her mother, who not only taught her the alphabet, but also introduced her to the joys of reading. We will return to this part of Zorlutuna's narrative in the second part of this chapter. Young Halide's most joyful moment came when her father was able to return from imprisonment and exile after the 1908 revolution. The language of her account, with the text interspersed with joyful exclamations like Yarabbî! [Oh Lord!], conveys some of the excitement that a small girl about seven years of age must have

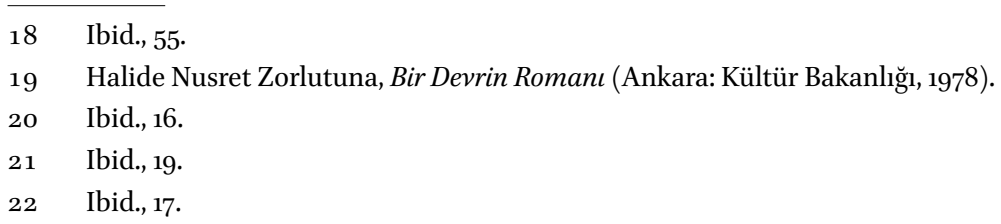


felt. The event was preceded by a major house-cleaning, Halide was dressed in new clothes and she was made to learn Namik Kemal's poem Hürriyet [Freedom] by heart in order to declaim it from the stair head when her father entered the house. She claims that she understood the sense of the poem perfectly: "Freedom was gained, and my daddy had come!" Zorlutuna recounts how the word and concept 'freedom' became forever illustrated and embodied in the triumphal return of her father to his family. ${ }^{23}$

İrfan Orga, an erstwhile Turkish army officer turned journalist, travel writer and biographer, lets the reader follow the dramatic transformation of a happy childhood world into chaos following the outbreak of the First World War, which left the family in disarray when Orga's father died of wounds during the Gallipoli campaign. Orga's autobiography Portrait of a Turkish Family ${ }^{24}$ (first published 1950) recounts in vivid and saddening detail how Orga's mother and grandmother tried to earn a living and keep the family from collapsing. This was made difficult by the fact that they were two rather pampered upper-class Ottoman ladies, used to leaving the practical affairs of life to their menfolk and servants. However, Portrait of a Turkish Family initially portrays a childhood idyll. The first five chapters of the book are devoted to introducing Orga's family, consisting of his parents, grandparents, his younger brother and the family servants, and to relating the author's earliest memories. The narrative is tinged sometimes with nostalgia, sometimes with humour. Some passages serve a double duty of conveying cultural or ethnological information, for example about Turkish baths and the circumcision ceremony for young boys. Orga wrote for a non-Turkish audience, so these passages were composed with both informing and entertaining the reader in mind.

Reflecting the title of his autobiography, Orga does not introduce his family members one by one, as some other authors do, but rather presents his early upbringing as a collective effort by the whole family, starting with his father who had an almost ritual obligation to begin his son's day by tossing little İrfan into the air a couple of times each morning. The boy was then handed, with admonishments to be good, to Inci, his young nursemaid. She would then proceed to the "prolonged battle" of washing her young charge and the "torture" of combing his hair. ${ }^{25}$ The nurse İnci was the daughter of another maid and whose father was a servant in the imperial household. The high number of servants in the household of Orga's extended family emphasize their elevated and privileged status.

23 Ibid., 21.

24 İrfan Orga, Portrait of a Turkish Family (London: Eland, 2004 [1950]).

25 Ibid., 8. 
The highlight of the day for the boy came when, ablutions concluded, he was handed to his mother for inspection and caresses. Orga describes his mother as the very pinnacle of beauty, refinement and delicacy, a creature more like a decorative porcelain figure than a living woman:

She was always very slender and liked to dress in pastel colours, soft shimmering silks that smelt of lavender water of eau-de-cologne. She was a gentle, silent person, her hands delicate and useless-looking and weighted down with the number of flashing rings that she invariably wore. [...] She rarely went out and never alone but spent most of her time on the terrace or sitting under a fig-tree in the garden, much as the women in her family had done for generations before her. She appeared perfectly happy, content to be solely an ornament in her husband's home. ${ }^{26}$

Orga continues the description with his grandparents, who, as grandparents the world over often do, spoiled him a lot. Several pages of his account are used to describe how he, as a boy, would accompany his grandfather on his morning walk to the coffee house, playing outside while his grandfather enjoyed his coffee and nargileh. Not being taken on these excursions, and generally the withdrawal of his grandfather's favour, was actually used as a punishment for various misdemeanours. ${ }^{27}$ The first irruption of loss and grief into this happy childhood world is presented very soon in Orga's narrative, when, on one of these morning walks, his grandfather suffered a stroke or seizure. The kindly old man was taken home to what turned out to be his deathbed. Orga claims to remember the events around his grandfather's death in great detail, even that he half-heartedly played with toy blocks while waiting to be called into the sick room to see his grandfather one last time. In an almost Proustian moment of clarity, Orga recalls how afterwards, sitting on the landing in front of his grandfather's room

I started to cry suddenly, [...] and I still remember, as if it were yesterday, how a big, fat wood pigeon flew past the window, coo-cooing in his soft throaty voice. It is still the best-remembered sound of that day. ${ }^{28}$

\footnotetext{
26 Ibid., 9 .

27 Ibid., 9-13.

28 Ibid., 15. The link between sensory perception and memory ('Proustian memory') is by now confirmed by neuroscientific research, see Susanne Nalbantian, Memory in Literature: From Rousseau to Neuroscience (Houndsmills: Palgrave Macmillan, 2003), 61.
} 
After this sad episode, Orga's narrative quickly veers back towards the idyllic and picturesque; the next family member to be portrayed, in the chapter "An Autocrat at the Hamam," is his grandmother. This formidable lady would go on weekly trips to the bathhouse [hamam], with little İrfan coming along until he was about five of six years old, the customary age when boys would no longer be allowed into the women's bath. The bathhouse was an institution of crucial importance for the social fabric of Ottoman cities. For women, whose access to public gatherings was strictly regulated and who lacked spaces like the coffee house or kiraathane open to men, the bath was almost the only place to socialize. The hamam not only fulfilled a hygienic function in a time when most houses had no individual bathrooms, but also served as a social club and 'wellness centre,' perhaps imaginable as a cross between a modern-day gym or health club and a café. The bath was an exchange for news and gossip, as well as a place where mothers of marriageable sons would inspect potential daughters-in-law and where alliances between families were brokered. ${ }^{29}$ İran Orga describes the hamam and his grandmother's excursions to the bath in great detail, an excellent example for the way in which 'Ottoman worlds' were presented to western audiences. By presenting the hamam as the scene for aspects of family life, Orga not only informs, but also 'turns around' western ideas about the hamam as a highly eroticized Orientalist fantasy, populated with voluptuous odalisques. ${ }^{30}$ Conversely, for a Turkish reader in the 1950s, accounts like this would have been heavy with their own memories, including nostalgia for an institution that was dying out as a result of the modernizing effort of the Turkish state. ${ }^{31}$

\section{House, Garden and Neighborhood}

Many Turkish or generally post-Ottoman autobiographies contain descriptions of the physical environments in which their authors grew up. I will take a look at these topics by examining some descriptions of houses, gardens and

29 On the meaning of the hamam in Ottoman culture, and the hamams of Istanbul in particular, see Kate Fleet and Ebru Boyar, A Social History of Ottoman Istanbul (Cambridge: Cambridge University Press, 2010), 249-270. For the story of one particular hamam through the ages, see Nina Chichoki (Ergin), "Continuity and Change in Turkish Bathing Culture in Istanbul: The Life Story of the Çemberlitaş Hamam," Turkish Studies, 6 (1), 2005, 98-112.

$30 \quad$ Nina Ergin, "Between East and West: Modernity, Identity and the Turkish Bath," Trondheim Studies on East European Cultures and Societies 29, 2010, 26.

31 Chichoki [Ergin], "Continuity and Change," 108. 
the neighbourhood [mahalle], all of them important dimensions in Ottoman society and in Turkish social life to the present day. As regards autobiography as the expression of an individual, the house in particular is recognized as crucial, as the setting for the development of a protagonist's personality and interior life, a notion closely connected to developmental psychology. ${ }^{32}$ Houses and domestic spaces are also useful concepts in observing a generation or a whole society; since they are products of a specific society, "they express and reinforce their norms, social practices and ideologies." ${ }^{33}$ In the Turkish context, the house, and in particular the type of house known as 'Ottoman house' or re-interpreted as 'Turkish house,' holds a special place in cultural heritage. Carel Bertram has demonstrated how the 'Turkish house' is firmly rooted in Turkish collective memory through its constant representation in literature and the visual arts. Bertram argues that the house is thus made much more of a collective or shared than a merely autobiographical memory. ${ }^{34}$ While this point is persuasive, I argue that this collective memory 'pool' is certainly fed by autobiography certainly feeds as autobiographies are produced, reprinted and consumed.

The traditional neighborhood within a town or village, the mahalle, is another crucial constant for Ottoman and post-Ottoman social life. The mahalle in its inhabitants as a body was important both as a framework for social relationships and as a group which controlled and regulated the moral or social behaviour of its members, for example by detecting and exposing unacceptable sexual behaviour. From Ottoman times, there are many sources relating violent and quite effective vigilante-type actions taken against criminals and those accused of 'immoral' behaviour. ${ }^{35}$ In the case of children, the mahalle also served a network within which they were looked after and controlled by a wider circle of persons than their immediate family, for example by neighbors. The neighborhood was thus a place in which solidarity as well as control was enacted. Thus was the physical as well as social context in which children functioned ${ }^{36}$ broadly similar basic

32 Kathy Mezei, "Domestic Space and the Idea of Home in Auto/Biographical Practices," in Marlene Kadar, Linda Warley, Jeanne Perreault and Susanna Egan (eds), Tracing the Autobiographical (Waterloo: Wilfrid Laurier Press, 2005), 85.

33 Ibid., 81.

34 Carel Betram, Imagining the Turkish House: Collective Visions of Home (Austin: University of Texas Press, 2008), 58.

35 Fleet and Boyar, Social History, 126-128. Mahalle baskısı [neighbourhood pressure] is still a well-known concept in contemporary Turkish social life.

$3^{6}$ Bekir Onur, Türk modernleşmesinde çocuk (Ankara: İmge, 2009), 213. 
structures and functions of domesticity and neighbourhood space can be found in many parts of the Ottoman Empire and they often transcend social boundaries as well.

this section will note how the triangle of childhood living space housegarden-mahalle was remembered and described by authors who grew up in this environment. My two following examples are drawn from provincial cities as well as contexts less refined than the genteel, middle class surroundings of the Ottoman capital which the reader has encountered earlier in this chapter or in Akşit's chapter of this volume.

In his autobiography Hayat Hikâyem (1973), ${ }^{37}$ the businessman Vehbi Koç (1901-1996) describes life in a provincial town, in this case Ankara, at the beginning of the twentieth century. In general, his account is very matter-of-fact, almost laconic; it gives an unadorned description of rather harsh realities without any kind of nostalgic embellishment. Koç compares the living conditions of his childhood with the present, describing how the people of Ankara had to make do without electricity and plumbing. Water to wash clothes was taken from wells located in peoples' gardens or, failing that, from neighbourhood wells, while poorer inhabitants drew water from streams. Bodily hygiene was attended to in public baths. Houses were lit by kerosene lamps, which according to Koç came in different kinds, classified by number. Thus, number eight lamps were used for reading; number fourteen lamps were only brought out for guests. The lack of electricity meant that perishable foodstuffs had to be lowered into wells to keep them cool. ${ }^{38}$ Another modern amenity lacking from "old Ankara" was street lighting. Koç relates how the townsfolk organized their daily schedule according to the daylight hours and corresponding Muslim prayer times, with shops opening at dawn and closing at sunset. When someone had to venture out after dark, for example to go on a visit, they would have servants carry candle lanterns [mum fenerleri] ahead of them. The lack of coal stoves or electric heating meant that in Vehbi Koç's youth, houses never seemed to be warm enough. He remembers how in winter, only one room was used for sitting in his home, to save heating fuel. To heat this sitting room, the family, like many others, used a brazier ${ }^{39}$ which was put under a low table with a quilt spread over it. The family would then sit around the table with their legs tucked

37 Vehbi Koç, Hayat Hikâyem (Istanbul: Vehbi Koç Vakfi, 1973).

38 Koç, Hayat, 9.

39 Called a kürsü by Koç, a word of Arabic origin which in Turkish usually means 'lectern' or 'pulpit.' Kursi or korsi is still used as a word for 'brazier' in Farsi. The more common Turkish word for brazier, also used in other autobiographies, is mangal. 
under the quilt. In the case of very severe cold, people in Ankara would resort to sealing windows with a paste of flour and water to improve insulation. ${ }^{40}$

Koç continues with some details on food and table culture. Among the details he gives is that pekmez (a type of molasses or treacle made from grapes) was used to sweeten tea when people could not afford sugar. Stressing the differences between 'then and now', the author describes how there were no bakeries or public bread ovens [şehir firunlart] in his childhood and how the families of his neighbourhood would bake bread in ovens in their own or their neighbours' houses. At the table, cutlery known to Koç's 1970s readers was in short supply. He remembers how only his grandfather used a knife and fork and a separate plate, while the rest of the family ate from a communal dish using wooden spoons. ${ }^{41}$

As he describes the house and the neighbourhood on the outskirts of Edirne in which he grew up, the writer, teacher and political publicist Şevket Süreyya Aydemir (1897-1976) paints a picture which is a mix of light and dark colours. In the first place, the reader becomes acquainted with surroundings far more basic than the living conditions in Vehbi Koç's childhood home. Aydemir's childhood world contrasts sharply with the sheltered, relatively refined worlds in which, for example, Ahmed Emin Yalman or Halide Nusret Zorlutuna grew up. Aydemir's city quarter was an almost rural area of small houses surrounded by gardens and orchards, connected by narrow alleys covered in dust in summer and mud in winter.

In his autobiography Suyu Arayan Adam (first published 1959), ${ }^{42}$ Aydemir initially presents an ambience of depression and latent violence due to the inter-communal tensions in the Ottoman Balkan provinces. In very captivating language, he creates an image of the physical environment which matches the feelings which the inhabitants may have had about their lives and times. The area Aydemir grew up in was on the outskirts [kenar mahalle] of Edirne, mainly inhabited by refugees (mühacır or göçmen in Aydemir's text) from the northern Balkan territories the Ottoman Empire had lost in the course of the nineteenth century. Aydemir matches the physical state of the neighborhood with the mental atmosphere in the way he describes the area as bası, meaning "low" both in the physical and the psychological sense. The houses on the neighborhood were very humble dwellings of mud-brick and wood, surrounded by gardens and

\footnotetext{
40 Koç, Hayat, 10.

41 Ibid., 11.

42 Şevket Süreyya Aydemir, Suyu Arayan Adam (2nd edition, Istanbul: Remzi Kitabevi, 1971 [1959]).
} 
connected by unpaved roads. ${ }^{43}$ Yet for all the poverty, violence and political uncertainty, Aydemir is also able to take pleasure in many aspects of his childhood life. His parents' house was typical for the area in having no running water or furniture except some wooden shelves; devoid of electricity, it was lit by candles and kerosene lamps. Aydemir recalls how his parental home was considered as one of the better houses of the neighbourhood, as it had more than one room and a separate kitchen. ${ }^{44}$

Furniture was non-existent, except for shelves used to store vegetables and hay-stuffed cushions [ot yastıkları]. The floors were covered with mats or kilims. Aydemir recalls his amazement at encountering a real chair and actually sitting on it in a barbershop in town, an adventure of such momentousness that he told his playmates about it for days. ${ }^{45}$ The living quarters served as storage areas for fruit and vegetables; Aydemir mentions corn cobs, pumpkins and strings of red peppers on wooden shelves, and bunches of grapes that were kept in dark corners away from dust. The only other accoutrements of the house were the already mentioned kerosene lamps and a water container with a copper drinking vessel kept next to the door. ${ }^{46}$ All this is stated by Aydemir in a matter-of-fact way, which does not necessarily read like an accusatory report on lower-class living conditions.

The space which alleviates the general drabness and poverty of Aydemir's childhood scenario is the garden of his childhood home. This garden was particularly well-tended and beautiful because, as Aydemir recalls, his father considered trees as "sacred creatures" and everyone in the house loved flowers. He himself, along with his mother, would plant different kinds of flowers around a terrace [taşlk $]$ behind the house and collect sods of turf from meadows around the town to put around the flowerbeds. Young Şevket and his mother would follow the growth and development of the plants carefully together. The blossoming of certain flowers, for example of a type of lily, was celebrated with the custom of decorating the flowers with tinsel. These occasions, he remembers "were feast days for our house." ${ }^{47}$ This passage is striking for its immediate proximity to sequences in the same chapter which describe violence and poverty. The garden of the childhood home is presented like a hospitable island in an extremely unfriendly environment.

\begin{tabular}{ll}
\hline 43 & Aydemir, Suyu Arayan, 12 ff. \\
44 & Ibid., 12. \\
45 & Ibid., 13. \\
46 & Ibid. \\
47 & Ibid., 12 ff.
\end{tabular}


The American writer Leon Sciaky (1894-1958) was born and raised in the vibrant Sephardic Jewish community of Ottoman Selânik (Salonica, modern Thessaloniki). He begins his autobiography, Farewell to Salonica: City at the Crossroads, ${ }^{48}$ not immediately with his parents, but instead guides the reader into the house in which he was born, and which had been the konak [mansion] of a high Ottoman official before becoming the Sciaky family home. Behind an unassuming facade, the house was spacious, divided into a public and a private sphere. Of the latter, the most important room was the main living room, in which, as Sciaky puts it, "the two antipodal tendencies which were to leave an indelible stamp on my life"49 — namely the polarity of Levantine and western European customs, tradition and modernity-was typified by the very furniture. One end of the room was filled with furniture made in Paris and Vienna (like a grandfather clock, walnut dining table, giltframed mirrors etc.), while the other-in sharp contrast—contained no furniture except two low divans covered with pillows. For Sciaky, it was as if the two halves of the room "glared uneasily at each other." Home is where the heart is: the Sciaky family would instinctively gravitate towards this "Oriental" side of the salon, the mother doing embroidery, the grandmother for a quiet cigarette. ${ }^{50}$ Sciaky gives this childhood scene a higher meaning in the interpretation of his personal fate. For him, the coexistence of two lifestyles in the microcosm of the home exemplified the two main cultural influences which were to shape his whole life.

One last aspect of mahalle life in Ottoman times deserves mention here. The omnipresent street dogs had always been a feature of everyday life in Ottoman towns and villages and caught the eye of almost every foreign or local observer. ${ }^{51}$ These animals, beloved neighbors rather than pests, also appear in autobiographical accounts, such as Riza Nur's Hayat ve Hatıratım. Nur gives a detailed account of these semi-feral dogs and the role they played in the life of his hometown. According to Nur, these dogs belonged to specific mahalles, did not cross the borders of their home territory, forcefully expelled every strange dog that ventured into their beat and also kept a watchful eye on

48 Leon Sciaky, Farewell to Salonica: City at the Rrossroads (London: Haus Books, 2007), 15.

49 Ibid., 15.

5o Ibid., 16. In the Gulf region today, the custom of having a traditionally furnished sitting room (majlis) as well as a modern one still exists (Information by Matthias Determann, SOAS).

$51 \quad$ Fleet and Boyar, Social History, $273 \mathrm{ff}$. On early modern European accounts, see Metin And, Onaltıncı yüzyılda İstanbul: Kent, saray, günlükyaşam (Istanbul: Yapı Kredi Yayınları, 2009), 90. 
human trespassers. While the dogs were considered unclean, Nur concedes that they had another vital function besides being guard dogs. Since there was no public garbage removal service in late nineteenth century Sinop, the townspeople would simply throw refuse into the streets, were it was eaten by the dogs. For this service, the dogs were much loved by their human neighbors. ${ }^{52}$ Up until this point, Nur's account closely resembles that of other authors, who mostly write about the street dogs of Istanbul. ${ }^{53}$ It is as if Riza Nur, eager to provide exact ethnographic information-as promised in his foreword-had to make sure to mention the street dogs, if only in a rather generic way. Nur does not give a more personal perspective on these ubiquitous animals until the end of the passage, when he mentions some favorite dogs which had names. Ever the fastidious auto-ethnographer, he mentions that these names were traditional names which had been given to Turkish dogs for centuries, such as Black Head [Karabas ], even if the dog in question had no black head. ${ }^{54}$

\section{'Childhood Culture'}

Many, if not most, autobiographical narratives of Ottoman childhoods include aspects that can be broadly defined 'non-physical', and which I would place under the umbrella term 'childhood culture.' By this I mean the games played by children, children's participation in and perception of religious ceremonies or feast days - which includes a glance at individual religious experiencesand cultural activity in a more narrow sense. This includes oral 'folk literature,' for example, storytelling; traditional performance, such as the shadow theatre, and the childhood 'discovery' of the printed word, of books and newspapers in the home setting.

Some childhood memories recall the clash of old and new, 'tradition and modernity.' Such stories and how they are presented offer a vivid insight into how authors of autobiographies perceived their childhood worlds in retrospect, and how they sometimes took sides in this conflict. I have therefore chosen to include a short section on the sometimes uneasy encounter of what was called in the late Ottoman parlance 'alla turca' and 'alla franga'55 cultures.

\footnotetext{
$52 \quad$ Nur, Hayat, $65 \mathrm{ff}$.

53 For one example, see Klaus Kreiser, Istanbul: Ein historisch-literarischer Stadtführer (Munich: C.H. Beck, 2001), $51 \mathrm{ff}$.

54 Nur, Hayat, 66.

55 Roughly translatable as 'in Turkish style' and 'in European (“Frankish") style.'
} 


\section{Games and Pastimes}

Riza Nur presents a very detailed account of the games and sports enjoyed by children as well as adults during his childhood in Sinop during the 1880s. Nur's almost ethnographic attention to detail lives up to the promise he gave in the introduction to Hayat ve Hatıratım, where he states that gathering such information is one of the purposes of his autobiography. He begins his section on the subject by stating without false modesty that even though he was smaller than many of the other children in his neighbourhood, he was chosen as their leader. ${ }^{56}$ He then presents a list of ten games with detailed explanations and their traditional names, from hide-and-seek [saklanbaç] or a form of tag [esir almacığı] to different types of ball games. The latter were also played by adults, in addition to cirit [javelin throwing on horseback] and horse races.

The exact details of the different games are not crucially important for us at this point. What is more interesting is the meaning and significance Nur gives to these games. He calls them "national games and sports" [Milli oyun ve sporlar], and places them in the larger context of the Turkish national heritage, stressing the fact that there are "national sports" in Turkey as well as in western countries. Nur deplores the fact that these games had been abandoned [terk edilmiştir] and explains this process as follows:

This means that there have been sports among the Turks just as among the contemporary Europeans. This means the Turks were very good [at this] in the past. Later they deteriorated. The Europeanizing [Avrupakârî] reform effort ruined them completely, because they demolished the old, national things and put those of the Europeanizers in their place. This renewal is for us merely an interregnum [fetret devri]. ${ }^{57}$

A few pages further on in his narrative, Ruza Nur returns briefly to a description of the sports played by adults during his childhood. These took place on Fridays and included wrestling [güreş], horse races [at yarışı], mounted javelin throwing [cirit oyunu] and ball games. He presents these pastimes as cultural assets about to become extinct; by the time he was twenty years old (that is, around 1900), games such as these were considered unsuitable for adults and were no longer practiced. Nur deplores this development: "How good were the customs of the ancestors, and how their progeny has sunk into ignorance [cehalet]!"58

$\begin{array}{ll}5^{6} & \text { Nur, Hayat, } 64 . \\ 57 & \text { Ibid., 65. } \\ 5^{8} & \text { Ibid., 69. }\end{array}$


The basic tenor of this account is, as in other parts of Nur's narrative, pride in a Turkish national heritage that is equal or superior to anything introduced during the Ottoman reform period by those he calls "Europeanizers." This criticism is actually twofold. First, it can be understood as aimed at the proliferation of alla franga influences during the last decades of the Ottoman Empire. However, it is useful for us to keep in mind that Nur had also become a vocal critic of the new republic and was forced into exile for his views. ${ }^{59}$ The dismissive labelling 'Avrupakâri' can equally allude to the Kemalist reforms which unfolded in Turkey while Riza Nur was in exile, cut off from his native land and its changing scene following his falling-out with the Kemalist regime in 1926.

\section{'Folk Literature,' Storytelling and Reading}

Şevket Süreyya Aydemir tells of evening gatherings in his family's house or garden. The women of the neighbourhood would assemble at a different house each evening, to socialize and exchange stories, sometimes about their own fate as refugees, or the latest news or rumours about guerrilla activities [komitacılık]. ${ }^{60}$ In a happier mood, the works of famous âşı poets would be recited at such gatherings. In addition, stories of wars, epics [destanlar] and love stories [aşkmasalları] such as those about Leylâ and Mecnun were told, as well as stories about fairies and jinns [cin peri hikâyeleri] ${ }^{61}$ The latter impressed the boy especially, who imagined the dramatis personae of jinns, fairies and giants becoming real in the dim light of the paraffin lamps. ${ }^{62}$

In spite of the poverty of the area, books were also present at these gatherings, out of which stories were read aloud. Aydemir recalls how the gatherings in which books were read were held only in his house, as his mother and he himself (having been taught by his mother) were the only persons in the neighbourhood who could read, and he also comments on the effects reading could have on a child in a largely illiterate environment. First of all, reading bestowed prestige. Aydemir remembers how he would have an appreciative audience, sitting in a large mulberry tree in his parents' garden or at the evening gatherings, reading from a collection [divan] of aşık poetry or books of legends, war stories and romances. He recalls that his performances made him a respected

\footnotetext{
59 See Adak, "Who is Afraid?" $127 \mathrm{ff}, 131$.

6o Aydemir, Suyu Arayan, 13, 23.

61 Ibid., 25 .

62 Ibid., 26.
} 
person for the adults in his community, despite his age, while the children of his own age accepted his slightly "different" status. ${ }^{63}$

As well as this, he also felt the effects of his reading matter: the stories he read or heard fired his imagination, making him want to participate in them and enabling him to leave his drab surroundings, if only in his thoughts. He was left with the dream of actually leaving and having adventures when he had finally grown up; ${ }^{64}$ and his autobiography shows that his wishes were eventually fulfilled. The First World War took him to the eastern Anatolian front; he lived in the Caucasus after the war and eventually moved to Moscow to study. On returning to Turkey, he was first imprisoned for his political beliefs, but eventually freed and then able to embark on a fruitful career; perhaps not the fanciful exploits young Şevket would have imagined—but adventures nonetheless.

As Duygu Köksal demonstrates in the final chapter in this volume, the Memoirs of Halide Edip ${ }^{65}$ contain very detailed reflections on cultural influences on the author, who presents herself as having been something of an 'inward-looking' child who spent a lot of time reading, or listening to stories. As a motherless girl growing up in a turbulent extended family, the family servants were an important constant in her early life, personalities who provided some measure of stability and who also told her folk stories. The first stories young Halide heard were Circassian folk tales told by Fikriyar, a servant of her stepmother. Halide Edip claims to remember little of these except a story about a particularly ghastly and frightening female demon. ${ }^{66}$ However, the most important supplier of stories to the little girl was the manservant Ahmed Ağa, who not only told stories but possessed books, cheap editions on "funny yellow paper" and in "bad Persian print," probably similar to the cheap books which Şevket Sürreya Aydemir mentions. ${ }^{67}$ The first book Halide read under the tutelage of Ahmed Ağa, who helped her make sense of difficult words and passages, was the great Turkish epic of Battal Ghazi, a heroic fighter against the Christians in medieval Anatolia. While this story of adventure and heroic exploits certainly captivated her younger self, Halide Edip remembers that it

63 Ibid., 23 ff and 26.

64 Ibid., 26.

65 Halide Edip Adıvar Memoirs of Halide Edip (London: John Murray, 1926).

66 Ibid., 9o. Halide Edip calls the demon peri, a term from Persian mythology which is more commonly used for more benign, fairly-like creatures.

67 Ibid., 115. Benjamin Fortna points out the similarities in Halide Edip's and Şevket Süreyya Aydemir's respective"reading careers," see Benjamin C. Fortna, Learning to Read in the Late Ottoman Empire and the Early Turkish Republic (Basingstoke: Palgrave MacMillan, 2011), $184 \mathrm{ff}$. 
she found her real hero in Ali, the champion of Shi'i Islam and another saintly hero. This figure appealed to her as a hero who not only put fear into his enemies, but also was a just leader under whom women and children felt secure and who "killed dragons that ate people up. He destroyed the personified fear of the primitive mind."68 It is not surprising to see how a girl like Halide Edip, shaken by a tumultuous family life, ${ }^{69}$ would turn towards a protector-figure like this. The tales she read in Ahmed Ağa's cheap books "opened to me the folklore, the popular Turkish literature which none of the rest of my generation of writers have enjoyed."70

Halide Nusret Zorlutuna also became a voracious reader in her early childhood, in her case due to the influence of her mother, who, as we have heard above, was "addicted to reading."71 Reading, alone or together with her mother, is among the most fondly remembered pastimes in Halide Nusret's childhood. She gives detailed information of what was read in her home. Her mother subscribed to several newspapers, a practice which according to the author was not common at the time. After the midday meal, Halide and her mother would lie on the bed together reading the newspaper İkdam. In addition, Zorlutuna's mother kept subscriptions for several other magazines, including the influential Hanımlara Mahsus Gazete [Ladies' Own Journal]. ${ }^{72}$

Other texts read — and recited — in the household were poems, for example by Namik Kemal, which little Halide would learn by heart and repeat "parrotlike" [papağan gibi], just as her first school lessons, without entirely understanding the content. The true meaning of the poems only dawned on her much later. This lead to a potentially embarrassing or even dangerous situation, as many of these poems were considered seditious and were banned during the reign of Sultan Abdülhamid II. Therefore, Halide's mother impressed upon the little girl never to recite these poems in public. ${ }^{73}$

Also among the literary influences in Halide Nusret Zorlutuna's life were serialized novels [tefrika romanlar] in the daily newspapers. These works were

68 Halide Edip, Memoirs, 115.

69 Along with the death of her mother, the subsequent polygamous marriages of her father. For a closer anlysis of Halide Edip's narrative position and technique, see Nazan Aksoy, Kurgulanmış benlikler: Otobiyografi, kadın, cumhuriyet (Istanbul: İlteşim, 2009), 82-90.

$70 \quad$ Ibid.

71 Zorlutuna, Bir Devrin, 17. For a more detailed discussion of Zorlutuna's and other authors' memories about reading, see Fortna, Learning to Read, 175-205.

72 Zorlutuna, Bir Devrin, 17. For a thorough study on this journal, see Ayşe Zeren Enis, Everyday Lives of Ottoman Muslim Women: Hanımlara Mahsûs Gazete (Newspaper for Ladies) (1895-19o8) (Istanbul: Libra, 2013).

Zorlutuna, Bir Devrin, 18. 
not only read, but transferred into the sphere of playing as well: Halide Nusret used to re-enact the adventures of the heroes in these novels with her dolls, sometimes matching the storyline, sometimes creating her own plot; ${ }^{74}$ the recollection of this episode clearly aims at showing the future woman of letters at work in an early outburst of creativity.

\section{Old and New, 'alla franga' and 'alla turca'}

Experiences of reform and innovation and the sometimes precarious coexistence of traditional and modern are salient topics in Middle Eastern autobiographical literature, and post-Ottoman Turkish autobiography is no exception. These experiences are sometimes related in the context of childhood.

In the case of Ahmad Emin Yalman, the state of coexistence of 'new' and 'old' was to be observed at close range in the home inhabited by his extended family. In this house, the boy Ahmed observed "two opposed worlds" [iki zıd âlem], typified by his father and his uncle. His amca, his paternal uncle, was firmly attached to a traditional way of life, punctual in his five daily prayers and observing every religious rule. He abhorred modern, 'western-style' pastimes such as worldly literature, the theatre and travel or inventions such as photography, and he held strong views on dress. He would never even touch a white shirt and starched collar and jacket, but instead wore a collarless shirt and long coat. $^{75}$

By contrast, Yalman's father was a man of the new times, described by his son in a shorter, earlier, English version of his autobiography as "progressive, perhaps even a revolutionary,"76 who went around in the highest starched collars he could get, and with colourful ties and suits according to the latest fashion. He loved poetry as well as music and the theatre, and was enthusiastic about travel. In spite of his brother's dislike of this modern technology, Ahmed's father had photographs taken of every member of the family (probably with exception of the amca) and displayed them framed on the wall. ${ }^{77}$ Yalman's mentioning of photographs is very interesting: several studies have shown how photography became an important part of Ottoman everyday culture in the

\footnotetext{
74 Ibid., $18 \mathrm{ff}$.

75 Yalman, Yakın tarihte, 21.

76 Ahmed Emin Yalman, Turkey in My Time (Norman: University of Oklahoma Press, 1956), 13.

77 Yalman, Yakın tarihte, $21 \mathrm{ff}$.
} 


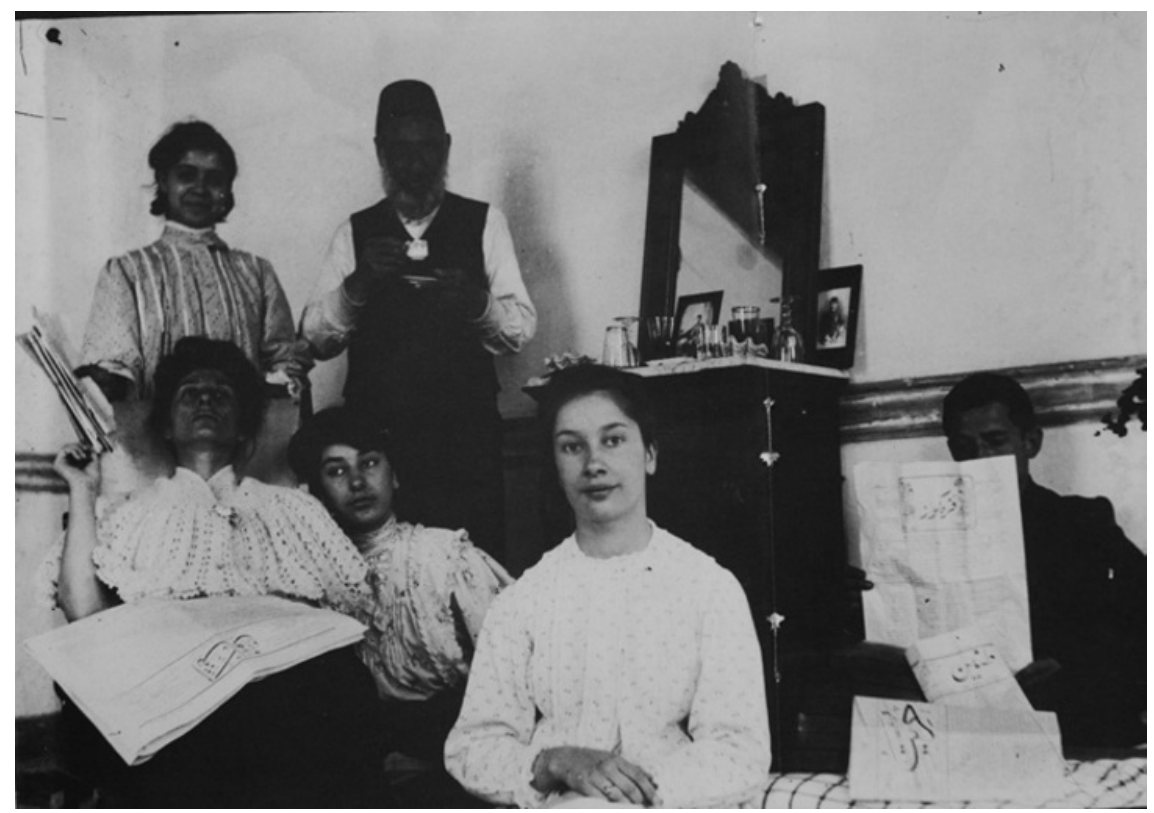

FIGURE 9.1 Photographer Ali Sami poses with his family.

mid-to-late nineteenth century. There is even visual evidence for how photographs were displayed in a domestic setting very much like that described by Yalman. In his study of how children learned to read in the late Ottoman Empire and early Turkish Republic, Benjamin Fortna complements his discussion of reading books and newspapers in a family setting with a photograph that shows the family of the photographer Ali Sami (Figure 9.1). Several individuals are gathered in a salon with a casual-looking but probably staged display of newspapers that were read by members of the family. The image also shows framed photographs displayed on a sideboard, in a similar way as they would have been found in Yalman's childhood home. This illustration, seen against Yalman's description, is a rather fascinating interaction: we can put side-by-side the textual (Yalman's autobiography) and visual (Ali Sami's photograph) depictions of photography in a family setting. ${ }^{78}$

$7^{8}$ For a more detailed discussion of this illustration and its implications, see Fortna, Learning to Read, 195. On the use of photography in late Ottoman families see also Nancy Micklewright, "Late Ottoman Photography: Family, Home and New Identities," in Relli Shechter, Transitions in Domestic Consumption and Family Live in the Modern Middle East: Houses in Motion (New York: Palgrave Macmillan, 2003), 65-84. For a discussion of this particular photograph, see page 80. 
Throughout his autobiography, Yalman voices open approval for modernization and change and his account of his uncle is very much in keeping with this overall tone. Yalman calls his uncle's attitude "conservatism and stagnancy" [muhafazarlikve durgunluk] and he accuses his uncle of having "neither need nor yearning for innovation, change or adventure."79

Kâzim Karabekir gives a very interesting account of both the technical innovations existing in Istanbul during his childhood as well as the ways in which technology was still lacking. He relates how people in Istanbul knew about some innovations, which were becoming standard elsewhere, only from newspapers or by word of mouth. Thus, Salonica already had an electric tramway, while the Ottoman capital had to be content with horse-drawn tramways, drawn by "weak hacks, in a deplorable state under the whip [of the drivers]." 80 The sorry state of the Istanbul tramway horses is a topic remarked on by many other contemporary authors. ${ }^{81}$ One detail which Karabekir leaves out in his account is that at the same time (in the 188os), the Tünel underground railway was already in service, contemporaneous to the underground railways being built in London and New York. At the same time, modern passenger steamships of the Şirket-i Hayriye ferry lines were already plying the Bosphorus. The most likely explanation for omitting this is probably that Karabekir meant to present the Ottoman capital under the old regime in as backwards a light as possible.

Likewise, the telephone and the automobile were only known from hearsay in Karabekir's childhood. It was only from travellers who had been to Europe that people in Istanbul heard about the proliferation of these technologies elsewhere. The first car Karabekir claims to have seen was a miniature model in a circus in Beyoğlu. ${ }^{82}$ Here, again, his account has to be taken with some degree of caution as research has shown that technological progress found its way into the Ottoman capital much faster than Karabekir suggests. ${ }^{83}$ Karabekir explains this state of affairs by Sultan Abdülhamid II's aversion to technology: the Sultan was "suffering from persecution mania" [vehimliymiş] and therefore was firmly opposed to any technological device which could be used either for the diffusion of seditious thought or pose a threat to the ruler's personal security. On the other hand, though, we again have to keep in mind that Abdülhamid

\footnotetext{
79 Yalman, Yakin tarihte, 22.

8o Karabekir, Hayatım, 175 .

81 Kreiser, Istanbul, $54 \mathrm{ff}$.

82 Karabekir, Hayatım, 175.

83 See for example the chapter on nineteenth-century Istanbul in Fleet and Boyar, Social History.
} 
was certainly not adverse to the use of technology when it suited his ends: the proliferation of railway and telegraph lines were both very useful in controlling an empire. ${ }^{84}$ It seems to me that Karabekir is less interested technology for itself, but rather recounts how there was a lack of technological progress as an opportunity to launch into a general tirade about how the Ottoman state declined under the rule of Abdülhamid. He also criticizes more generally the lack of knowledge, and of the free exchange of ideas and information:

While Macedonia was on fire $[. . .]^{85}$ nobody in Istanbul knew a thing. Every [enemy] nation took enormous measures towards our ruin; we committed a crime by not getting information and not spreading news to our fellow countrymen. God confound it [Allah kahretsin], what despotism! The poor uninformed people were biddable and humble as sheep and the most disastrous [thing was] that they believed a man who had not even received a primary education enjoyed all prosperity and felicity [solely] by virtue of being omnipotent and God's deputy on earth. And whoever did not believe it was imprisoned for saying or writing this. ${ }^{86}$

The passage, almost a rant, is an excellent example of how an autobiographical narrative of an author's childhood environment can be extended into criticism in a wider context, in this case the way the Ottoman state was run in the late nineteenth century.

\section{Conclusion}

This chapter has drawn attention to three main themes common in memories of Ottoman childhoods. The first is the sense of the authors as bearing witness. The authors describe what was for them reality, but what is history for their readers - or shared history if the reader happens to be a contemporary of the author. With some authors this amounts to a mere description, sometimes a comparison of 'back then' versus 'now,' as in Vehbi Koç's account. Whether such a narrative has meaning beyond the description of facts is hard to say,

84 Karabekir, Hayatım, 174. Sultan Abdülhamid's peculiar position on technology and his pathological fear of coups and assassinations is well known, see François Georgeon, Abdulhamid II: Le Sultan Calife (Paris: Fayard, 2003), 159-164.

85 The exact meaning is not made clear, but Karabekir either refers to the $1875^{-1878}$ 'Great Eastern Crisis' or the unrest in Macedonia which preceded the 1908 Young Turk Revolution.

86 Karabekir, Hayatım, 175 . 
but it possible that an author like Koç is trying to get his reader thinking about the relative ease of the reader living in the 1970s, compared to houses without electricity and plumbing in the Ankara of Koç's childhood. A similar case could be made in reading Şevket Süreyya Aydemir's childhood story.

Sometimes it is possible to detect within these descriptions of the past a hint, to a greater or lesser degree, of criticism of the present, the time when the author was writing. In its most trenchant form, we see this in Ruza Nur's description of material culture, especially the games and sports played in Sinop during his childhood. Nur's account moves from a matter-of-fact, ethnosociological description into a flamboyant speech in defence of these games as dying cultural assets and against a current of, in his opinion, artificial and unhealthy modernization. Once more, the author's personal circumstances explain the tone of the narrative: Nur himself had been in the service of first the Ottoman state, as a doctor, and then the Turkish Republic, as minister, diplomat and National Assembly member. However, once rejected by the state, accused of sedition and forced into exile, Nur dips his pen into a rather acidic ink and accuses both entities of diluting the national heritage.

While the tone of the description ranges from relatively neutral to belligerent with some authors, in others it is tinted with nostalgia, as in the case of İran Orga, opening up a second dimension of childhood memories. In Orga's autobiography, his family takes centre stage and the narrative appears as an effort to bring back to life and commemorate the lost human cast of his life story. ${ }^{87}$ The element of nostalgia and sadness is — understandably—strongest in authors displaced from their native land and in some cases living in exile, precisely the situation Orga found himself in when writing his childhood memoir.

A third theme intertwined into the pages of childhood memory is the question of how the 'past world' has affected the author, what lasting meaning authors ascribe to their childhoods. This leads us directly to the way in which autobiographical memories of Ottoman childhoods told to a post-Ottoman audience contribute to answering our main question. Throughout this chapter, we have been concerned with finding out how the 'Ottoman world' is described. Generally, the Ottoman setting of an author's early years is never unambiguously praised or condemned in childhood narratives. Many authors had generally happy childhoods, but even with them, some negative influences can be detected, be it the death of a relative as with İrfan Orga or a harsh, strict father figure as with Ruza Nur. The fact of having grown up in a specific location at a certain time becomes especially fraught with meaning

$87 \quad$ See specifically Orga, Portrait, 9. 
when authors contextualize their personal lives with the historical events taking place around them. Most, if not all autobiographies used in this analysis give some sense of personal lives being affected by historical events at a time rich in change and turmoil. Some authors accentuate this aspect of their remembering more than others. Halide Nusret Zorlutuna includes several such episodes in her childhood memories, not all of which could be discussed here. I have, however, shown one example, her story of her father's return to his family after the 1908 revolution. Zorlutuna describes this event as a national and personal red-letter day: "Freedom was gained, and my daddy was home!"

This is but one anecdote. If one were to look at more texts and in more detail, other and more illustrative examples would come to light. For instance, Şevket Süreyya Aydemir's childhood narrative is an even more extensive example of the contextualization of childhood with history unfolding around the child, as he closely interweaves the account of his early life with the sad story of Rumeli. He shows a child growing up literally within earshot of the bitter violence that marked life in the Ottoman Balkan provinces during the early twentieth century.

Another important function of the 'Ottoman childhood' is having made persons what they are. Authors, for instance, remember learning from their parents, for example through their parents' exemplary character, as in the case of Riza Nur or Kâzim Karabekir. Sometimes children learned from their parents quite literally, being taught to read or write, as Halide Nusret Zorlutuna was by her mother. The intellectual, cultural content of the Ottoman world-'cultural capital,' as one could call it—was imparted during childhood. We have heard about storytelling and reading as ways for this cultural process of passing on knowledge, by parents, other relatives or family servants.

One could of course argue that the same, or very similar, types of cultural practices were still in use during the Turkish Republic — so how is a 'Republican childhood' different from an 'Ottoman' one? On the one hand, obviously some aspects of Ottoman childhoods, like certain cultural practices, were irretrievably lost or in danger of dying out when the autobiographers penned their works. Once again, one could mention Riza Nur as an example. He deplores the disappearance of the pastimes of his childhood days not only as a loss in itself, but as damage to the national cultural heritage. His critical stance takes on a third dimension if read generally as criticism of the 'new regime,' something which at first surprises the reader but which makes a lot of sense given that the later parts of Nur's vast autobiography are concerned with precisely this line of criticism. Another example would be Halide Edip remembering the different ways in which she 'consumed' popular literature and especially the works of the Turkish folk tradition and Middle Eastern classics, such as Persian 
epics. She deplores that contemporary Turkish writers (of the time when she was writing, the late 1920s) do not make more use of this rich tradition, which was a bold statement at a time when the language and script 'revolutions' were about to get under way and the cultural politics of the Turkish Republic were geared towards moving away from 'old style' forms and genres. Thus, childhood memories could not only mean memory of things past alone, but also serve as a template for criticizing the author's present.

\section{Bibliography}

\section{Primary}

Aydemir, Şevket Süreyya, Suyu Arayan Adam, 2nd edition, Istanbul: Remzi Kitabevi, 1971 [1959].

Edip Adıvar, Halide, Memoirs of Halide Edip, London: John Murray, 1926.

Karabekir, Kâzım, Hayatım, 2nd edition, Istanbul: Yapı Kredi Yayınlanı, 2009.

Koç, Vehbi, Hayat Hikâyem, Istanbul: Vehbi Koç Vakfi, 1973.

Nur, Riza, Hayat ve Hatıratım, 1 , Istanbul: Altındağ Yayınevi, 1967.

Onur, Bekir, Türk modernleşmesinde çocuk, Ankara: İmge, 2009.

Orga, İfan, Portrait of a Turkish Family, London: Eland, 2004 [1950].

Yalman, Ahmed Emin, Turkey in My Time, Norman: University of Oklahoma Press, 1956.

Yalman, Ahmed Emin, Yakın tarihte gördüklerim ve geçirdiklerim, ı, Istanbul: Yenilik, 1970.

Zorlutuna, Halide Nusret, Bir Devrin Romanı, Ankara: Kültür Bakanlığı, 1978.

\section{Secondary}

Adak, Hülya, "Who is Afraid of Riza Nur's Autobiography?" in Olcay Akylldz, Halim Kara and Börte Sagaster (eds), Autobiographical Themes in Turkish Literature: Theoretical and Comparative Perspectives, Würzburg: Ergon, 2007, 125-141.

Aksoy, Nazan, Kurgulanmış benlikler: Otobiyografi, kadın, cumhuriyet, Istanbul: İteşim, 2009.

And, Metin, Onaltıncı yüzyılda İstanbul: Kent, saray, günlükyaşam, Istanbul: Yapı Kredi Yayınlan, 2009.

Betram, Carel, Imagining the Turkish House: Collective Visions of Home, Austin: University of Texas Press, 2008.

Chichoki [Ergin], Nina, "Continuity and Change in Turkish Bathing Culture in Istanbul: The Life Story of the Çemberlitaş Hamam," Turkish Studies, 6 (1), 2005, 98-112.

Enis, Ayşe Zeren, Everyday Lives of Ottoman Muslim Women: Hanımlara Mahsûs Gazete (Newspaper for Ladies) (1895-1908), Istanbul: Libra, 2013. 
Ergin, Nina, "Between East and West: Modernity, Identity and the Turkish Bath," Trondheim Studies on East European Cultures and Societies 29, 2010, 1-27.

Fleet, Kate and Ebru Boyar, A Social History of Ottoman Istanbul, Cambridge: Cambridge University Press, 2010.

Fortna, Benjamin C., Learning to Read in the Late Ottoman Empire and the Early Turkish Republic, Basingstoke: Palgrave MacMillan, 2011.

Freitag, Ulrike and Nora Latf, "Daily Life and Family in an Ottoman Urban Context: Historiographical Stakes and New Research Perspectives," History of the Family, 16 (2) 2011, 80-87.

Georgeon, François, Abdulhamid II: Le Sultan Calife, Paris: Fayard, 2003.

Kafadar, Cemal, "Self and Others: The Diary of a Dervish in 17th Century Istanbul and First Person Narrative in Ottoman Literature," Studia Islamica, 69 (1989), 121-150.

Kreiser, Klaus and Patrick Bartsch (eds), Türkische Kindheiten, Frankfurt am Main: Literaturca, 2012.

Kreiser, Klaus, Istanbul: Ein historisch-literarischer Stadtführer, Munich: C.H. Beck, 2001.

Lejeune, Philipp, On Autobiography, translated by Katherine Leary, Minneapolis: University of Minnesota Press, 1989.

Mezei, Kathy, "Domestic Space and the Idea of Home in Auto/Biographical Practices," in Kadar, Marlene, Linda Warley, Jeanne Perreault and Susanna Egan (eds), Tracing the Autobiographical, Waterloo: Wilfrid Laurier Press, 2005, 81-95.

Micklewright, Nancy, "Late Ottoman Photography: Family, Home and New Identities," in Relli Shechter, Transitions in Domestic Consumption and Family Live in the Modern Middle East: Houses in Motion, New York: Palgrave Macmillan, 2003, 65-84.

Morrison, Heidi, "What is the Global History of Childhood?" in Heidi Morrison (ed.), The Global History of Childhood Reader, Abingdon: Routledge, 2012, 1-8.

Nalbantian, Susanne, Memory in Literature: From Rousseau to Neuroscience, Houndsmills: Palgrave Macmillan, 2003.

Reynolds, Dwight F. (ed.), Interpreting the Self: Autobiography in the Arabic Literary Tradition, Berkeley: University of California Press, 2001.

Reynolds, Dwight F., "Childhood in One Thousand Years of Arabic Autobiography," Edebiyât, 7, 1997, 379-392.

Sciaky, Leon, Farewell to Salonica: City at the Crossroads, London: Haus Books, 2007. 